Indonesian Journal of EFL and Linguistics

Vol. 3 No. 1, 2018

eISSN: 2503-4197, pISSN: 2527-5070

www. indonesian-efl-journal.org

\title{
Writing Skill of Engineering Students of Government and Self-financing Colleges: A Comparative Study
}

\author{
J. Saravanan \\ $V V$ College of Engineering, Tirunelveli, Tamil Nadu, India \\ e-mail: lingu.saravanan21@gmail.com \\ A. Prakash \\ VV College of Engineering, Tisaiyanvilai, India. \\ e-mail:pallasathene.zeus@gmail.com \\ R. Saravana Selvakumar \\ $V V$ College of Engineering, Tisaiyanvilai, India. \\ e-mail:sskumar.kumar19@gmail.com
}

\begin{abstract}
:
This study compares and analyses the writing performance of engineering students studying in government and Self-financing colleges in Tuticorin district. The subjects of the study comprised of 75 randomly selected first year students from three engineering colleges located in Tuticorin district. The elicitation instrument used for the present study was essay writing and the subjects were asked to write an essay on "Advantages and Disadvantages of using mobile phone." Descriptive method was adopted for collecting data. The errors were identified and classified into ten categorizations like verb tense, subject-verb agreement, prepositions, conditional sentences, singular/plural form, sentence fragment, word order, spelling, capitalization and double negatives. The results showed that the engineering students made seven most common errors in verb tense, subject-verb agreement, prepositions, conditional sentences, singular/plural form, sentence fragment and word order due to lack of understanding, poor acquisition of grammar rules, intra-lingual errors and interference of the learners' mother tongue.
\end{abstract}

Keywords: Importance of writing; Essay writing; Error analysis; Statistical analysis

Indonesian Journal of EFL and Linguistics, Vol. 3(1), 2018 


\section{INTRODUCTION}

At present, English plays an essential role for one's successful career. In the effective use of English, it is important to master the four language skills namely listening, speaking, reading and writing (LSRW). Of the four language skills in English, writing is an important language skill which is required to express the thoughts in formal and informal situations. However, this skill has always been considered an obstacle for the engineering students, especially in examination. The difficulty of writing lies in the fact that it encompasses different aspects of language. Indeed, grammar, vocabulary, organization and content are among the skills to develop for good writing. They make writing complex to teach Supriyanto (2013). The ability to write effectively requires extensive and specialized instruction; consequently there are a number of professionals in colleges, universities and workplaces to acquire it. The ability to communicate ideas and information effectively through the global network is crucially dependent on good writing skill. It is used for different purposes that engineers will perform in their daily activities like writing letters, memos, email messages, proposals, minutes, project reports, assignments, lab experiments and so on. They now have less time to improve their writing skill during the four year engineering course which meets the needs of their profession. They need excellent writing skills to survive professionally and excel in their subject matters academically.

Referring to the importance of writing in Of Studies, Francis Bacon says that reading makes a full man; conference a ready man; and writing an exact man. $\mathrm{He}$ also states that writing only makes a man perfect, so a learner has to practice a lot in order to produce a good piece of writing. Lamb and Jhonson (1999, p.173) state that writing is the expression of language in the form of letters, symbol or word. The symbols have to be arranged according to certain convention, to form words, and words have to be arranged to form sentences. Hughey et al (1983) say that writing depends mainly on the words the writers choose and the form they give to their ideas. Each idea, word and structure must be chosen carefully, as once in the reader's hand there is no immediate feedback to rephrase, start again or classify statements. According to Liu \& Braine (2005) writing is a more complex skill that tests a person's ability to use a language and the ability to express ideas, as a result, a person needs to write not only coherently but also correctly, which requires more time and effort. It encourages thinking and learning and helps thought process available for reflection. When thought is written, ideas can be examined, reconsidered, added to, rearranged and changed. Langan (1987) and Gunning (1998) agreed that writing is difficult, more complex and abstract than talking. Moreover, Parker (1993) supported this view when he stated that writing could be torment to students. Therefore it is evidently true that writing poses a number of problems to the engineering students, as it is a skill that is difficult to master. Besides that, teachers too face great challenge to teach these skills and conventions as students may at times find them confusing and difficult to understand and write effectively in English. This paper therefore, describes an effort to compare the performance of 
writing skill encountered by the engineering students and analyse the factors behind their writing proficiency.

\subsection{Statement of the Problem}

The present study is undertaken to find out the reasons, how and why the engineering students fail to develop the skill of writing during the four year course.

\subsection{Objectives of the Study}

This study aims to shed new light on the following two objectives:

1. To compare and analyse the performance of writing skill by the engineering students studying in Government and Self-financing colleges.

2. To identify and classify the types of errors encountered by the engineering students studying in Government and Self-financing colleges.

\subsection{Research Questions}

Based on the objectives, the following research questions are posed to be answered throughout the study.

i) What types of errors are found most common in essay writing?

ii) ii) What are the major problems that the engineering students faced in essay writing?

\section{LITERATURE REVIEW}

Several studies have tried to shed light on the sources of writing skills of engineering students' performance by examining the subject using various tools on different populations in a particular way. Keeping in view the above fact, the present study tries to highlight the importance of writing for the engineering students, compares the performance of writing skill of Government and Self-financing colleges and finds the difficulties in writing encountered by them. The errors in written English of standard VII students of rural schools of Palghat, Kerala were studied by Sangeetha (1996). The aim of the study was to identify the nature of errors in written English and to make a comparative study of the occurrence of different types of errors made by the students. She found that students made errors in sentence construction and preposition. The problem in the structural aspect of English language was found to be the cause for poor achievement. These findings coincided with those of Subramaniam (1981), Patrikar (1991); Mohammed (1986). Hourani (2008) examined the common types of grammatical errors made by Emirati secondary male students in their English essay writing. The most common and salient grammatical errors which were found in the students' essays included: passivization, verb tense and form, subject-verb agreement, word order, prepositions, articles, plurality and auxiliaries. The findings of the study revealed that the UAE students make grammatical errors due to two main reasons: interlingual and intralingual errors.

Darus and Subramaniam (2009), using Corder's (1967) model on error analysis, examined errors in a corpus of 72 essays written by 72 Malay students. They found

Indonesian Journal of EFL and Linguistics, Vol. 3(1), 2018 
that students' errors were of six types, viz., in singular/plural form, verb tense, word, subject-verb agreement, word choice, preposition and word order. Intralingual transfer of Malay and developmental errors were also observed in the students' writing. Ngadda and Nwoke (2014) investigated to analyze the errors found in the written English of the first year undergraduate engineering students of Federal University of Technology, Abubakar Tafawa Balewa University (ATBU), Bauchi. The researchers observed that errors occurred mostly in grammar, followed by expression, punctuation, spelling, vocabulary and the use of connectives. Mother tongue interference, faulty teaching and learning, intralingual difficulties and lack of much exposure to the target language are the possible causes of errors in the students' written materials. Mohammed Adam and Uthman (2015) examined that the possible causes of grammatical errors made by Sadui University students in composition writing. The findings of the study revealed clearly that the wrong tense errors followed by prepositions and verb to be the most frequent syntactical errors made by the respondents. They also showed that negative transfer from the mother tongue is the major cause of most of the syntactical errors made by the students in the written text. Many studies have been done for assessing the writing skill of engineering students from different perspectives. However, the present study which intends to compare the performance of writing skill of engineering students encounters difficulties while writing an essay in English. As no such research has been carried out earlier, this study will be helpful to the teachers of English in identifying the difficulties in writing.

\section{RESEARCH METHODOLOGY}

\subsection{Location}

The location of the study was three Engineering Colleges in Tuticorin District which are approximately 25 kilometers away from Tisaiyanvilai, Tuticorin district, Tamil Nadu, India. The colleges have two teaching sessions, namely the morning and afternoon session.

\subsection{Participants}

In the present study, a sample of seventy five first year undergraduate students were selected randomly from two Self-financing (40) and a Government (35) college located in Tuticorin district. Of them, 25 were males and 50 were females. The target participants were first year undergraduate students pursuing engineering course for the academic batch of 2016-2020. Descriptive method was used for collecting data.

\subsection{Data Collection and Instrument}

The investigation involves the use of questionnaire and the subjects were asked to write an essay on "Advantages and Disadvantages of using mobile phone." A sample of 75 essay writing scripts from three engineering colleges in Tuticorin district was collected for the research. Qualitative analysis was taken up in order to find the difficulties of the subjects while writing an essay. The data were tabulated 
and analysed through SPSS 16.0 version. Then, the types of error, the number of errors, percentage and mean value were displayed using the tables.

\section{DATA ANALYSIS}

In order to analyse the types of errors, the errors were identified and categorized into ten types like verb tense, subject-verb agreement, prepositions, singular/plural form, conditional sentences, sentence fragment, word order, spelling, capitalization and double negatives. Table 1 shows the analysis of errors based on the types of error, number of errors, percentage and mean value made by the engineering students from Self-financing colleges.

The data obtained below were classified and processed based on the objectives of the study. Taking the mean value of errors shown in Table 1, the results of the engineering students from Self-financing colleges show that they have made seven most common errors while writing an essay like verb tense (7.01), subject-verb agreement (6.13), prepositions (5.43), singular/plural form (4.75), conditional sentences (4.23), sentence fragment (3.38), word order (2.68). Then, the least number of errors made were spelling (2.25), capitalization (1.68) and double negatives (1.10). The results revealed that verb tense, subject-verb agreement, preposition, singular/plural, conditional sentences, sentence fragment were considered to be the complex areas while writing the essay.

Table 1: Analysis of Errors

\begin{tabular}{|c|c|c|c|c|}
\hline S. No. & Type of error & No. of errors & $\begin{array}{c}\text { Percentage } \\
(\%)\end{array}$ & Mean value \\
\hline 1 & Verb tense & 279 & 18.1 & 7.01 \\
\hline 2 & Subject-verb agreement & 245 & 15.9 & 6.13 \\
\hline 3 & Preposition & 217 & 14.1 & 5.43 \\
\hline 4 & Singular/Plural form & 190 & 12.3 & 4.75 \\
\hline 5 & Conditional Sentences & 169 & 11.0 & 4.23 \\
\hline 6 & Sentence fragment & 135 & 8.7 & 3.38 \\
\hline 7 & Word order & 107 & 7.0 & 2.68 \\
\hline 8 & Spelling & 90 & 5.8 & 2.25 \\
\hline 9 & Capitalization & 67 & 4.3 & 1.68 \\
\hline 10 & Double negatives & 44 & 2.8 & 1.10 \\
\hline \multicolumn{2}{|c|}{ Total } & 1543 & 100 & \\
\hline
\end{tabular}

Table: 2:

\section{Most Common Errors and Example of Errors (Self-financing Engineering Colleges)}

\begin{tabular}{|c|c|c|c|}
\hline $\begin{array}{c}\text { Classification of } \\
\text { errors }\end{array}$ & \multicolumn{1}{|c|}{ Identification of errors } & \multicolumn{2}{c|}{ Correct sentences with explanation } \\
\hline Verb tense & $>\begin{array}{l}\text { People are not use mobile } \\
\text { phones in the olden days. }\end{array}$ & $>\begin{array}{l}\text { People didn't use mobile phone in } \\
20^{\text {th }} \text { century. } \\
\text { People who were use mobile } \\
\text { phone continuously more than } \\
\text { three hours had eye damage. }\end{array}$ & $\begin{array}{l}\text { People who use mobile phone } \\
\text { continuously more than three hours } \\
\text { will have eye damage. }\end{array}$ \\
\hline
\end{tabular}




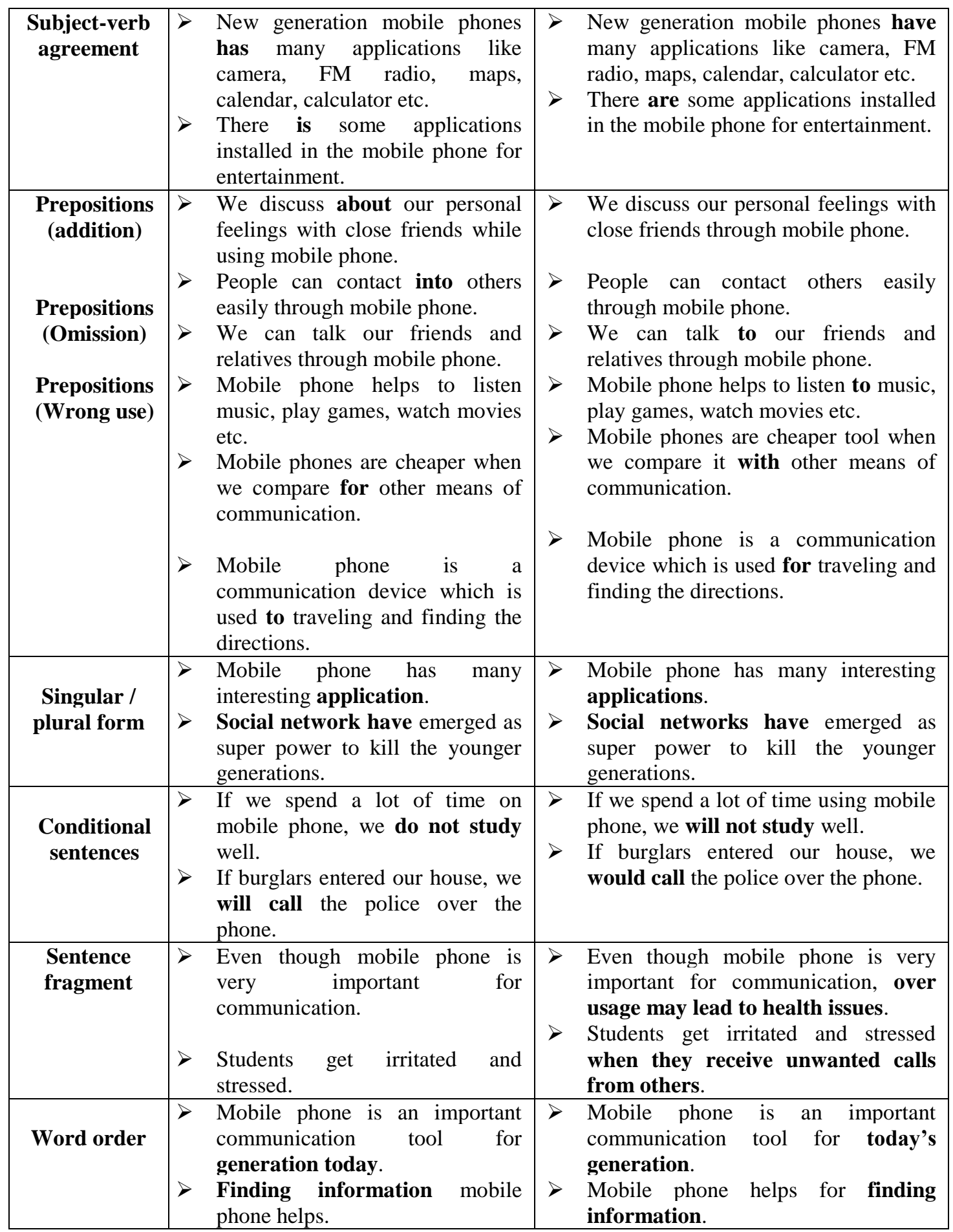

\subsection{Errors in Verb tense}

Nair and Chandrika (2011, p.237) say that tense indicates the time of an action or event. The tense of a verb expresses the time of an action and the degree of its completeness. It tells us whether it took place in the past (The Past tense), whether it 
is happening now (The present tense) or whether it will take place sometime in the future (The Future tense). The total number of errors found in this category was 279 which came to the mean value of 7.01 .

* People are not use mobile phones in the olden days.

* People who were use mobile phone continuously more than three hours had eye damage.

The most frequent errors made by the engineering students from Self-financing colleges are related to verb tense. The respondents had difficulty in selecting the appropriate tense to the verb in the sentences when they try to convey the meaning in a particular situation. The sentences above are structurally and grammatically incorrect because the respondents have not used the tense form of the verbs correctly. Based on the sentences above, it has been found that the errors made by the students in using the wrong selection of 'are not use', selection of 'were go' and selection of 'had', where the students are suggested to use 'didn't use', 'use and 'will have'. These types of errors are intralingual and another possible cause of error is false concept hypothesized. Such errors also occur due to the poor mastery of the uses of tenses. The data support the claim of Sukasame, Kantho and Narrot (2014) that learners of English as a second language have so much difficulty on tense selection.

\subsection{Errors in Subject-verb agreement}

Hult (2016, p.114) says that each subject must agree in number with its verb (he looks, they look); if the subject is plural, the verb must also be plural, but if the subject is singular, the verb must also be singular. Most of the second language learners have trouble in finding the agreement of the subject.

* New generation mobile phones has many applications like camera, FM radio, maps, calendar, calculator etc.

* There is some applications installed in the mobile phone for entertainment.

On analyzing the above errors, the subject-verb agreement appears to be the most problematic area faced by the engineering students from self-financing colleges. For example in the above sentence, the plural subject 'New generation mobile phones' does not agree with the verb 'has'. Another example occurred in the second sentence, the correct verb should be 'are' because the noun 'some applications' (plural). Dorn (2000) states that sentences created by words and phrases are the essential blocks of meaning that allow us to communicate our thoughts. If the sentences are not constructed properly, they can make reading difficult. Based on the fact that subject-verb agreement is very important to express our ideas especially in writing and the students need to master these rules in order to write effectively.

\subsection{Errors in Prepositions}

Koneru (2011, p.130) states that a preposition is a word that shows the relationship between an object and some other words in the sentence. It has an object, which is usually a noun or a pronoun. For example, Find a reference book from the library. 
In this sentence the word 'from' shows the relationship between two things - 'book' and 'library'.

\subsubsection{Addition of Preposition}

* We discuss about our personal feelings with close friends while using mobile phone.

* People can contact into others easily through mobile phone.

In English, certain verbs co-occur with prepositions while certain other verbs do not. The above usage is attributed to the mother tongue's interference. In the above construction 'about' is not needed as the verb 'discuss' means 'talk about'. That is to say, the verb 'discuss' carries the meaning of 'about'. Therefore, the unwanted use of preposition 'about' makes the sentence ill- formed. This type of error is attributed to the respondents' lack of knowledge in the use of preposition. In the second sentence, respondent has used redundant use of preposition. The collocational problem occurs since the transitive verb 'contact' actually requires a direct object rather than a prepositional phrase. The respondent could be influenced by the usage of 'contact' as a noun, where the preposition 'with' is indispensable. The learner forgets this kind of lexical restriction and makes mistakes while writing.

\subsubsection{Omission of Preposition}

* We can talk our friends and relatives through mobile phone.

* Mobile phone helps to listen music, play games, watch movies etc.

The appropriate preposition 'to' is obligatory but the respondent fails to use the simple preposition in the first construction. The above construction revealed the omission of preposition that seemed to be caused by the respondent's mother tongue (Tamil). The learner's error occurs because the verb 'listen', always requiring the prepositional phrase introduced by 'to', cannot be immediately followed by a noun. The instance clearly shows the spoken form of English practiced in schools that has given rise to this erroneous application of preposition.

\subsubsection{Wrong use of Preposition}

* Mobile phones are cheaper when we compare for other means of communication.

* Mobile phone is a communication device which is used to traveling and finding the directions.

Instead of selecting the correct combination of prepositional verb 'compare with'; one of the respondents has used the wrong prepositional verb 'compared for', which does not suit the above context. The expected prepositional verb 'compared with' refers to compare things that are very different (Merriam-Webster Learner's Dictionary). The complexity of the rules in the usage and placement of verb preposition does contribute to confusion in application among learners of their target language. The second sentence elicited from the response gave a clear picture that the respondent did not use the proper preposition 'for' while writing the essay on mobile phone. This error is attributed to mother tongue interference. 


\subsection{Errors in Singular/plural form}

Roshan (2016, p.13) states that a singular noun means only one noun, i.e. it refers to only one thing or person. A plural noun means more than one noun, i.e. it refers to more than one thing or person. The noun cat is used when it refers to only one cat; its form is singular. The noun cats is used when it represents more than one cat; its form is plural, says Altenberg and Vago (2010, p.9).

* Mobile phone has many interesting application.

* Social network have emerged as super power to kill the younger generations.

Instead of using 'many interesting applications', one of the respondents got confused to use the incorrect singular form 'many interesting application'. The noun 'application' is an error because it is used to refer to singular form, but the respondent should use the correct noun phrase 'many interesting applications'. In the second sentence above, one of the respondents was not sure when she/he should apply the plural form 'social networks'. This type of error is indicated by the absence of ' $-\mathrm{s}$ ' in plural noun where it is required. These kinds of errors occur due to the respondent's lack of knowledge of the rules of the target language and lack of attention.

\subsection{Errors in conditional sentences}

Rao (2009, pp.61-62) states that conditional sentences are used to show how one action depends on the other. The meaning of conditional sentences depends on the verb forms, which have several different patterns. They consist of two clauses, the if-clause and the main clause. For example, If it rains, we will postpone the picnic. There are mainly three types of conditionals. They are 1) the condition may or may not be fulfilled and the simple present in the if-clauses refers to the future 2) to talk about improbable conditions or unreal situations and the simple past in the if-clause refers to the present or the future (not the past) 3) something did not happen because a certain condition was not fulfilled and the past perfect refers to something that did not happen.

*If we spend a lot of time on mobile phone, we do not study well.

* If burglars entered the house, we will inform the police over the phone.

Conditional sentences ranked fourth on a list of most common errors encountered by engineering students. In the first sentence, the right form is after the 'if clause' must use 'will not study well'. The concordance of verb patterns is not perfectly wellformed in the first conditional clause. This type of error is purely due to lack of interest and consciousness in constructing if clauses in the second language situation. In the second example, the respondent made an error will inform instead of would inform in the main clause. This source of error brings out the confusion in the mind of the second language learner due to ignorance of rules. 


\subsection{Errors in Sentence Fragment}

Goldstein and Waugh (2010, p.104) state that a sentence is an independent clause containing a subject and a verb; it can stand by itself to express a complete thought but a sentence fragment lacks an essential quality of what makes a sentence a complete thought. For example,

Fragment: Went to the mall to buy a birthday gift.

Sentence: My friend went to the mall to buy a birthday gift.

- Even though mobile phone is very important for communication. (over usage may lead to health issues.)

- Students get irritated and stressed. (when they receive unwanted calls from others.)

The total number of errors found in this category was 135 , which came to $8.7 \%$. The respondent has not given the main clause due to the literal translation of L1 into L2 in the first sentence. This error could be attributed failure because the sentence didn't convey the full meaning. The main clause should be followed by the subordinate clause but the respondent fails to convey the meaning in the second sentence. This error can be assumed due to the interference of the mother tongue and lack of knowledge in framing the sentence.

\subsection{Errors in Word order}

Word order is very important in English. Hult (2016, p.263) states that changing the order of words in English sentences can actually change meaning. The subject-verb order is fixed, and we can change it only if there is a special reason. E.g.

The arm chair was damaged. (The "arm chair" is a piece of furniture.)

The chair arm was damaged. (One part of the chair, the arm, was damaged.)

* Mobile phone is an important communication tool for generation today.

* Finding information mobile phone helps.

The respondents made 78 word order errors due to the mother tongue's interference and lack of knowledge in sentence construction. Instead of using 'today's generation'; the respondent has written 'generation today'. This source of error also occurs due to respondent's carelessness. Another example of a word order occurred in the second sentence. The learner has not used the correct form of the prepositional phrase 'for finding information' which is supposed to be used after the verb in sentence. The error might be due to the translation of thoughts from L1 into L2.

Table 3: Analysis of Errors

\begin{tabular}{|c|l|c|c|c|}
\hline S.No. & \multicolumn{1}{|c|}{ Type of error } & No. of errors & Percentage (\%) & Mean value \\
\hline 1 & Verb tense & 204 & 18.9 & 6.11 \\
\hline 2 & Subject-verb agreement & 171 & 15.8 & 4.89 \\
\hline 3 & Preposition & 150 & 13.9 & 4.29 \\
\hline 4 & Singular/plural form & 128 & 11.9 & 3.66 \\
\hline 5 & Conditional sentences & 113 & 10.5 & 3.23 \\
\hline 6 & Sentence fragment & 101 & 9.4 & 2.89 \\
\hline 7 & Word order & 78 & 7.2 & 2.23 \\
\hline
\end{tabular}

Indonesian Journal of EFL and Linguistics, Vol. 3(1), 2018 


\begin{tabular}{|c|l|c|c|c|}
\hline 8 & Spelling & 63 & 5.8 & 1.80 \\
\hline 9 & Capitalization & 44 & 4.1 & 1.26 \\
\hline 10 & Double negatives & 27 & 2.5 & 0.77 \\
\hline \multicolumn{2}{|c|}{ Total } & $\mathbf{1 0 7 9}$ & $\mathbf{1 0 0}$ & \\
\hline
\end{tabular}

Table 3 shows the analysis of errors based on type of error, number of errors, percentage and mean values of errors made by the respondents. Taking the mean value of errors given in Table 3, the results of the engineering students from Government college show that they made errors while writing the essays like verb tense (6.11), subject-verb agreement (4.89), preposition (4.29), singular/plural form (3.66), conditional sentences (3.23), sentence fragment (2.89), word order (2.23), spelling (1.80), capitalization (1.26) and double negatives (0.77). On analyzing the data, it is observed that the major sources of errors in essay writing might be attributed to mother tongue interference, false concept hypothesized in verb form, overgeneralization in subject-verb agreement, first language interference in prepositions and failure to construct meaningful sentences which is influenced by L1 in the $\mathrm{L} 2$ context.

Table: 4:

Most Common Errors and Examples of Errors (Government Engineering College)

\begin{tabular}{|c|c|c|c|}
\hline $\begin{array}{c}\text { Classification } \\
\text { of errors }\end{array}$ & \multicolumn{1}{|c|}{ Identification of errors } & Correct sentences with explanation \\
\hline Verb tense & $>\begin{array}{l}\text { Mobile phones have completely } \\
\text { changed the way people } \\
\text { interacting with others. }\end{array}$ & $\begin{array}{l}\text { Mobile phones have completely } \\
\text { changed the way of people who } \\
\text { interact with others. }\end{array}$ \\
\hline $\begin{array}{l}\text { We will be get the exam results } \\
\text { through mobile internet. }\end{array}$ & $>\begin{array}{l}\text { We get the exam results through } \\
\text { mobile internet. }\end{array}$ \\
$\begin{array}{l}\text { Sugrect-verb } \\
\text { agreement }\end{array}$ & $>\begin{array}{l}\text { Mobile phones distracts the } \\
\text { students from their studies. } \\
\text { Mobile phone is one of the best } \\
\text { invention in the world }\end{array}$ & $>\begin{array}{l}\text { Mobile phones distract the students } \\
\text { from their studies. } \\
\text { Mobile phone is one of the best } \\
\text { inventions in the world. }\end{array}$ \\
\hline
\end{tabular}




\begin{tabular}{|c|c|c|}
\hline $\begin{array}{c}\text { Prepositions } \\
\text { (addition) }\end{array}$ & $\begin{array}{l}>\text { Students play games through } \\
\text { mobile phone a whole day and get } \\
\text { tired on next day. } \\
>\text { We will call up our friends and } \\
\text { relatives who are away from to us. } \\
>\text { We can now communicate } \\
\text { instantly people by using mobile } \\
\text { phone. } \\
>\text { We cannot concentrate our studies } \\
\text { if we had been using mobile phone } \\
\text { a long time. } \\
>\text { Don't waste your time in the } \\
\text { internet while using mobile phone. } \\
\text { Mobile phone is used for } \\
\text { communication in our relatives } \\
\text { who are working in foreign } \\
\text { countries. }\end{array}$ & $\begin{array}{l}>\text { Students play games through mobile } \\
\text { phone a whole day and get tired next } \\
\text { day. } \\
>\text { We will call up our friends and } \\
\text { relatives who are away from us. } \\
>\text { We can now communicate instantly } \\
\text { with people by using mobile phone. } \\
>\text { We cannot concentrate on our } \\
\text { studies if we use mobile phone for a } \\
\text { long time. } \\
>\text { Don't waste your time on the } \\
\text { internet while using mobile phone. } \\
\text { Mobile phone is used for } \\
\text { communication between our } \\
\text { relatives who are working in foreign } \\
\text { countries. }\end{array}$ \\
\hline $\begin{array}{c}\text { Singular/ } \\
\text { Plural form }\end{array}$ & $\begin{array}{l}\text { Nowadays, children's are very } \\
\text { much interested in playing online } \\
\text { games. } \\
\text { We can get a lot of informations } \\
\text { through mobile phone. }\end{array}$ & $\begin{array}{l}>\quad \begin{array}{l}\text { Nowadays, children are very much } \\
\text { interested in playing online games. }\end{array} \\
>\text { We can get a lot of information } \\
\text { through mobile phone. }\end{array}$ \\
\hline $\begin{array}{c}\text { Conditional } \\
\text { sentences }\end{array}$ & $\begin{array}{l}>\text { If a person had a mobile phone } \\
\text { with a net connection, everything } \\
\text { will be bought online. } \\
\text { If people are used mobile phones } \\
\text { while walking on the road, they led } \\
\text { to an accident. }\end{array}$ & $\begin{array}{l}\text { If a person had a mobile phone with } \\
\text { a net connection, everything could } \\
\text { be bought online. } \\
\text { If people use mobile phone while } \\
\text { walking on the road, they will meet } \\
\text { with accident. }\end{array}$ \\
\hline $\begin{array}{c}\text { Sentence } \\
\text { Fragment }\end{array}$ & $\begin{array}{l}\text { Contact mobile phone in danger. } \\
>\text { Due to radiation from the mobile } \\
\text { phone towers. }\end{array}$ & $\begin{array}{l}\text { Mobile phone helps to contact } \\
\text { others when we are in danger. } \\
\text { Many birds have died due to } \\
\text { radiation from mobile phone towers. }\end{array}$ \\
\hline Word order & $\begin{array}{l}>\text { Students do not sleep on time and } \\
\text { spend most of their time for } \\
\text { internet browsing. } \\
>\text { Nowadays, students games play } \\
\text { through mobile phone. }\end{array}$ & $\begin{array}{l}>\text { Students don't sleep on time and } \\
\text { spend most of their time for } \\
\text { browsing internet. } \\
>\text { Nowadays, students play games } \\
\text { through mobile phone. }\end{array}$ \\
\hline
\end{tabular}

\section{ERRORS IN VERB TENSE}

The use of verb tense shows that the engineering students from the Government college find it difficult to use the tense form of the verb. There are some examples taken from the respondents' essays to show the occurrences of errors in Tenses.

* Mobile phones have completely changed the way people interacting with others.

* We will be get the exam results through mobile internet. 
The incorrect verb 'interacting' from the respondent has to be substituted with the correct tense form 'interact' in the first sentence. The relative pronoun 'who' is omitted where it is required. The source of this error revealed the incorrect verb form and the relative pronoun that seemed to be caused by the respondent's mother tongue. In the second sentence, the use of the form is considered ungrammatical and the respondent should have used 'get' to make the sentence grammatically correct.

\subsection{Errors in Subject-verb agreement}

* Mobile phones distracts the students from their studies.

* Mobile phone is one of the best invention in the world.

Instead of selecting the correct subject-verb agreement 'distract', one of the respondents has written 'distracts'. The learner is confused with the appropriate use of the verb that is suitable for the subject of the sentence. This error may be because of lack of knowledge in the use of subject-verb agreement. In the second sentence, 'One of the best invention' refers to more than one and requires plural noun 'inventions'. This error might have occurred due to ignorance of rules.

\subsection{Errors in Prepositions}

\subsubsection{Addition of Preposition}

* Students play games through mobile phone a whole day and get tired on next day.

* We will call up our friends and relatives who are away from to us.

In English, the preposition 'on' is used before the days like 'on Monday, on Tuesday' etc. So, this rule tends the learner to extend the use of preposition where it is not possible in English, like 'on next day' in the first sentence. The respondent overgeneralized due to analogy or rote learning of rules resulted from their ignorance of rule restrictions. The redundant preposition in the second sentence is unnecessary. The preposition 'to' in the context is a literal translation of L1 into L2.

\subsubsection{Omission of Preposition}

* We can now communicate instantly people by using mobile phone.

* We cannot concentrate our studies if we had been using mobile phone a long time.

In the first construction 'with' is needed as the verb 'communicate' means 'to share information'. This particular error took place in the form of literal translation from L1 to L2. In the second sentence, the prepositions 'on' and 'for' are omitted in positions where they are required. The lexical item 'concentrate on' referred to direct one's attention and efforts towards a particular activity, subject or problem. The respondent might have thought in his/her L1 and then translate the same into L2.

\subsubsection{Wrong use of Preposition}

* Don't waste your time in the internet while using mobile phone.

* Mobile phone is used for communication in our relatives who are working in foreign countries. 
The respondent has selected the incorrect functional category 'in' instead of the appropriate preposition 'on' in the above context. The error is due to a result of literal translation of L1 into L2. Another example in the second construction, the respondent has not used the correct preposition 'between'. The incorrect preposition 'in' referred to place or area, or surrounded or closed off by something, whereas the substitution of preposition 'between' used in the context means to show the relation of two people or things. The source of error is attributed to mother tongue interference of the learner.

\subsection{Errors in Singular/Plural form}

* Nowadays, children's are very much interested in playing online games.

* We can get a lot of informations through mobile phone.

The number of errors in the use of singular and plural forms was 128, which represents $11.9 \%$ of the total errors. Instead of using the plural form 'children', one of the respondents has failed to use the inappropriate plural noun 'children's' in the first sentence. This error indicated that the addition $-s$ in the irregular plural noun form is due to overgeneralization and lack of knowledge in the use of singular/plural form. The word 'information' does not have a plural form in the second example. The respondent got confused to add an affix 's' in the end of uncountable noun. This source of error is due to lack of awareness and misapplication of rules.

\subsection{Errors in conditional sentences}

* If a person had a mobile phone with a net connection, everything will be bought online.

* If people are used mobile phones while walking on the road, they led to an accident.

The sentence first showed that the respondent has a problem in using the main clause of second conditional. The correct main clause has to be substituted with 'everything could be bought online'. The source of error could be attributed to lack of understanding the context and failed to use the correct verb form in the main clause. One of the respondents has not used the correct verb forms in the if clause and main clause in the second sentence. The respondent made the errors 'are used' and 'led to' instead of using 'use' and 'will meet with'. This error is due to the interference of L1 and ignorance of rules.

\subsection{Errors in Sentence Fragment}

* Contact mobile phone in danger. (Mobile phone helps to contact others)

* Due to radiation from the mobile phone towers. (Many birds have died.)

The above sentence elicited from the response, gives a clear picture that the respondent has not conveyed the meaning. This source of error may have caused due to the interference of L1 and lack of knowledge on how to construct a meaningful sentence. This error also could be due to lack of understanding sentence construction owing to poor learning. The second sentence "*Due to radiation from the mobile phone towers' should be 'Many birds have died due to radiation from the mobile phone towers'. This error could be attributed to the respondent's poor knowledge of the structure of English. 


\subsection{Errors in Word order}

* Students do not sleep on time and spend most of their time internet browsing.

* Nowadays, students games play through mobile phone.

It is clear that the gerund 'browsing' comes after the preposition in the second sentence. The right construction is 'browsing internet'. The learner incorrectly arranged the words in this sentence. This error could be attributed to mother tongue interference of the learner and lack of arranging the words in a proper order. Instead of using 'Students play games', one of the respondents got confused and arranged the words incorrectly 'Students games play'. This error is due to respondent's carelessness and lack of knowledge.

\section{RESULTS AND DISCUSSION}

This study aimed at comparing and analyzing the performance of writing skill encountered by the engineering students studying in Government and Self-financing colleges in Tuticorin district. It is observed from the data that the engineering students face many difficulties in writing. The results revealed that the respondents made errors while writing the essay such as: verb tense, subject-verb agreement, prepositions, conditional sentences, singular/plural form, sentence fragment, word order, spelling, capitalization and double negatives. An engineering student needs listening, speaking, reading and writing skills. Mastery in these four skills will provide a good future for him/her. Presently, the students of engineering college lack written language skills. The society and the colleges expect the students to get more marks rather than improving their real potential. The fundamentals of writing skills are not taught to them properly in schools and the students lack interest in learning the same. Even though some students speak a little English, they are very weak in writing skills. Lack of grammar knowledge of one major hurdle a student of the engineering college faces. Lack of exposure to writing is another important thing that cripples a student. Based on the results, it is inferred that the total number of errors found in the essays of the engineering students from Self-financing colleges was 1543 errors which constitute of about $59 \%$ when compared to the students from the Government engineering college, 41\% (1079) of errors (See Table 1 and 3). The students from Government engineering college performed better than the engineering students from Self-financing colleges in writing. The reason for the performance may be due to self-learning and motivation which result in effective participation. The other reason may be getting exposure from the learning environment and awareness of English language. Also, the foundation they have had plays a vital role in the process of acquiring English skills. All the Government engineering colleges have experienced professors whereas most of the engineering colleges have professors with minimum years of experience. The admission of the creamy layer in Government engineering colleges in contrast to the private engineering colleges is one of the main reasons for the sharp difference in the quality of English of Government and private engineering colleges.

A comparison between the engineering students from Self-financing and Government colleges showed that the students from Self-financing colleges made

Indonesian Journal of EFL and Linguistics, Vol. 3(1), 2018 
the highest number of errors (279) in the use of verb tense when compared to Government college students (204). The reason for the performance may be due to the learners' mother tongue and lack of knowledge in the use of verb tense. Cowan (2008, p.350) says that use of verb forms is one of the two or three most difficult areas for English language learners to master. Also, the staff members in the private colleges are forced to give good results and they give notes and force their students to memorize the text rather than understanding it. The admission of low quality students, the futile efforts of the teachers to get good results without imparting practical knowledge, and the incessant classroom exams conducted with a view to getting good results play a major role in the poor quality English of the students of the private engineering colleges. Most of the classroom sessions are without any interaction between the teacher and the students. Moreover, the students admitted in the private colleges are bent on getting degrees rather than practical understanding of grammar or English skills. The intake of low mark scorers and creamy layer is the key factor in determining the English of the students. As for subject-verb agreement errors, it was found that students encounter a serious problem in using the correct form of the structure. The problem is that the learner fails to use the proper rule of subject-verb agreement. The least number of errors was made by the students from the Government college found double negatives accounting for 27, which constitutes $2.5 \%$ of errors when compared to Self-financing colleges $44(2.8 \%)$. This would be attributed to carelessness and lack of knowledge. The present study corroborates with the findings of previous study Darus and Subramaniam (2009) with Malay high school students as participants identified mostly syntactic errors as the most common type seen in the essays examined, such as verb tense and word order. The result supports that the finding of Sangeetha (1996), who claimed that students made errors in sentence construction and preposition. The problem in the structural aspect of English language was found to be the cause of poor achievement. The findings of the present study corroborates with the findings of Ngadda and Nwoke (2014), who claimed that first year undergraduate engineering students of Federal University of Technology made errors due to interference of L1, intra-lingual errors and faulty teaching and learning are the possible causes of errors in the students' written materials. Adam, Uthman and Abdalla (2015) claimed that wrong tense errors, prepositions, article errors were found to be the most frequent ones. The findings revealed that negative transfer from the mother tongue is the major cause of most of the syntactical errors made by the students in the written text. However, the result also supports the findings of Hourani (2008), who claimed that the students made different types of grammatical errors, and most of these errors were due to intralingual transfer.

\subsection{Research Question: 1}

What types of errors are found most common in the essay writing?

After the analysis of errors, the findings reveal that errors occurred in the essays written by the engineering students are verb tense, subject-verb agreement, prepositions, singular/plural form, conditional sentences, sentence fragment, word order, spelling, capitalization and double negatives. The researchers found that there

Indonesian Journal of EFL and Linguistics, Vol. 3(1), 2018 
were seven types of errors to be the problematic areas and most common errors made by the engineering students like verb tense, subject-verb agreement, prepositions, conditional sentences, singular/plural form, sentence fragment and word order.

\subsection{Research Question: 2}

What are the major problems that the engineering students faced in essay writing?

Based on the findings, the reason for the major problems that engineering students faced in essay writing may be due to interference of L1, intralingual error, poor mastery of English grammar, illogical sequence of ideas, wrongly constructed sentences, ordering the words, lack of interest, carelessness, ignorance of rules restrictions, false concept hypothesized and overgeneralization. The researchers also state that sentence construction is the greatest challenge respondents' face in writing essays. This is due to lack of ability to use appropriate words and phrases in meaningful sentences.

\section{CONCLUSION}

The present study aimed at comparing and analyzing the performance of writing skill of engineering students studying in Government and Self-financing colleges. It also focused to identify and classify the types of errors made by them. It could be concluded that the performance of writing skill of the engineering students made different types of errors due to interference of the learner's mother tongue, intralingual errors, poor acquisition of grammar rules and lack of understanding in English structure. Based on the findings, the researchers suggested that the teacher must handle these problematic areas to predict the errors through diagnostic test and develop their teaching techniques, methods, and drills accordingly. They should help students avoid making grammatical errors and make it flawless by focusing their attention on the common errors which second language learners often make. Teachers are not much exposed to the modern day teaching which utilizes technology. As a result, the students who join engineering college in this district lack basic knowledge in written skills. Result oriented teaching is an important factor that affects the writing skill of the students. The following points are recommended to improve the written skill of the engineering students:

1. Sentence structure should be properly taught to the engineering students in the first semester.

2. Importance should be given to tense, subject-verb agreement, prepositions and conditional sentences.

3. Students have to be encouraged to learn basic grammar and write flawlessly.

4. Students should be taught to use technology to learn more things.

5. Reading habit should be inculcated among the students of engineering colleges.

6. Written exercises can be given and corrected immediately to show the students where they make mistakes while writing. 


\section{REFERENCES}

Adam, M., \& Uthman, A. (2015). An Analysis of Common Grammatical Errors made by Saudi University students in Writing. Express, an International Journal of Multi Disciplinary Research, Vol.2, Issue 3, ISSN: 2348- 2052.

Arfah, N.H.A. (1988). The Performance of Malay High School Students on Subjectverb agreement measured by Four Testing Methods. Unpublished M.A. Dissertation. Colorado State University.

Altenberg, P.E., \& Vago, M. R. (2010). English Grammar: Understanding the Basics (p. 9). New York: Cambridge University Press.

Brown, H.D. (2001). Teaching by principles: An interactive approach to language pedagogy $\left(2^{\text {nd }}\right.$ ed.). White Plains, New York: Pearson Education.

Cowan, B. (2008). The Teacher's Grammar of English (p. 350). Cambridge: Cambridge University Press.

Darus, S., \& Subramaniam, K. (2009). Error Analysis of the Written English Essays of Secondary School Students in Malaysia: A Case Study. European Journal of Social Sciences, 8(3), 483-495.

Dorn, D. (2000). Building Essays: A reader centred writing guide. New Jersey: Prentice Hall.

Ellis, R. (2002). The Study of Second Language Acquisition (p. 58). New York: Oxford University Press.

Farsani, G.S., \& Pourbafrani, M. (2015). Investigating Error Analysis of EFL University Students in Writing English Essays. International Conference on Humanities, Psychology and Social Science, Iran.

Goldstein, B., \& Waugh, J. (2010). Grammar to go: How it works and How to use it (p.104). United States: Cengage Learning.

Gunning, T.G. (1998). Assessing and Correcting Reading and Writing difficulties. Boston: Allyn and Bacon.

Hourani, Y. (2008). An Analysis of the Common Grammatical Errors in the English Writing made by $3^{\text {rd }}$ Secondary Male Students in the Eastern Coast of the $U A E$. Unpublished Master Thesis, British University, Dubai.

Hughey, J.B. et al. (1983). Teaching ESL Composition: Principles and Techniques. Massachusetts: Newbury House.

Hult, A. C. (2016). The Handy English Grammar (pp. 114, 263). United States: Visible Ink Press.

Koneru, A. (2011). English Language Skills (p. 130). New Delhi: Tata McGraw Hill Education Pvt. Ltd.

Lamp, A., \& Johnson, L. (1999). Writing. http://42explore.com/writing.htm Retrieved May 12, 2011.

Langan, J. (1987). College Writing Skills. New York: McGraw Hill.

Liu, M., \& Braine, G. (2005). Cohesive features in argumentative writing produced by Chinese Undergraduates. Vol.33, Issue 4, pp. 623-636 <www.sciencedirect.com>

Nair, V.K.A., \& Chandrika, A. (2011). English Grammar without Tears (p. 237). New Delhi: University Science Press.

Indonesian Journal of EFL and Linguistics, Vol. 3(1), 2018 
Ngadda, Y. Z., \& Nwoke, A. (2014). An Analytical Study of Errors in the Written English of Undergraduate Engineering Students, ATBU a Case Study. Journal of Education and Practice, Vol.5, No.38, ISSN 222-1735.

Parker, S. (1993). The Craft of Writing. London: Paul Chapman Publishing Ltd.

Rao, P. (2009). New Learners' English Grammar and Composition (pp.61-62). New Delhi: Blackie ELT Books.

Roshan, A. (2016). Me ' $n$ ' Mine English Grammar (p. 13). New Delhi: New Saraswati House (India) Pvt. Ltd.

Sangeetha, T.V. (2000). Opinion of primary school teachers towards the use of computers. Unpublished M.Ed. (Technology) Dissertation. University of Calicut.

Supriyanto, J. (2013). The effect of mind mapping strategy on the students writing ability. JP3, 1(13), 184-190.

Villanueva, A. (2008). An International Comparative study on English writing proficiency in two secondary school settings. Lärarprogrammet $90 \quad p \quad /$ Didaktiskt Examensarbete $i$ Engelska Handledare: Oliver St. John. (http://www.divaportal.org/smash/get/diva2:211250/fulltext01.pdf) 